\title{
BANISHMENT: CRUEL AND UNUSUAL PUNISHMENT
}

\section{MtChati F. ARMSTrong $\dagger$}

In the course of the South's current struggle with its race problem, increasing efforts have been made to remove, not the problem, but the race. "Freedom riders" are told by judges and warned by governors to get out and stay out; "sit-ins" are advised that there are no seating problems at lunch counters in New York City; Senators present plans to finance a Negro exodus to Africa; and citizens councils provide free bus transportation and pocket money for voluntary exile to Hyannisport.

So far, the means used to effect this solution have generally been limited to the application of pressures such as financial inducement, simple persuasion, economic harassment, social and political coercion, and, occasionally, a judicial prod. Indeed, it would seem clear that a vast majority of the large number of Negroes abandoning the South$1,457,000$ of them did so between 1950 and $1960^{1}$-are subjected only to those pressures inherent in an environment they consider to be unfriendly and without promise.

However, as southern Negroes become more organized, begin to generate identifiable aims, and produce local leaders to articulate them, southern whites may realize that individual troublemakers can be disposed of and crowded jails emptied by means of a simple, time honored, though somewhat archaic method of legal compulsionbanishment for life. The idea would seem more appropriate to Romeo and Juliet or Great Expectations than to the solution of problems in a modern society. Most people today think of banishment, if at all, only in relation to fiction, antiquity, or both. "The device of thrusting out of the group those who have broken its code is very ancient and constitutes the most fearful fate which primitive law could inflict. The offender . . . was driven forth naked into the wild." 2 Genesis relates that Adam and Eve were banished from Eden, and "it has indeed been contended that the mark set on Cain was not so much a miraculous or talismanic sign for the protection of his life, as a sign probably connected with one of the most ancient of all forms of judicial punish-

$\dagger$ A.B. 1954, Yale University; LL.B. 1960, Harvard University. Member, New York Bar.

1 N.Y. Times, April 29, 1962, §4, p. 8, col. 6.

2 Plucknett, Outlawry, 11 ENcyc. Soc. Scr. 505 (1933). 
ment [-banishment]." ${ }^{3}$ The ancient civilizations of Babylon, ${ }^{4}$ Greece, ${ }^{5}$ and Rome ${ }^{6}$ employed banishment, and England made extensive use of it for centuries. By the mid-nineteenth century, however, the English lost interest in banishing citizens. "No power on earth, except the authority of parliament, can send a subject of England, not even a criminal, out of the land against his will." 7

At the time the Union was formed, banishment did not appeal to the United States, which had so recently been used as a depository for Europe's "refuse."

[T] he idea of such laws would have been repulsive to men of that time [1789]. Banishments were a thing of the remote past .... Very likely the Constitution would have failed of ratification if the members of the state conventions had been told that the proposed national government would be able to throw people out of this country. ${ }^{8}$

Banishment, however, did not go the way of the pillory and the whipping post. ${ }^{9}$ Although banishment of a citizen from the country has in recent years been no more than a theoretical possibility, at the state level banishment exists as a practical fact. Trial judges and magistrates still impose banishment, often without naming it as such. ${ }^{10}$ Overt sentences of banishment are common in the handling of vagrants. ${ }^{11}$ Governors make banishment a condition for pardon. ${ }^{12}$ Most significant, perhaps, is the fact that more widespread use of the practice in this country may merely await the awakening of state legislatures

3 Fink, Crimes and Punishments Under Ancient Hindu Law, 1 L. MagazInE \& REv. (4th ser.) 321, 333 (1875).

4 Harper, The Code of Hammurabi King of Babylon 55 (1904) (§154 of the Code).

5 Chafee, Three Human Rights in the Constitution of 1787, at 205 (1956).

6 Sutherland \& Cressey, Principles of Criminology 268 (6th ed. 1960).

74 Hawkins, Pleas of the Crown 298 (7th ed. 1795).

8 CHAFEe, op. cit. supra note 5, at 205-06. The practice was not entirely repugnant to the colonists, however, as is illustrated by the cases of Roger Williams and Anne Hutchinson. See Douglas, An Almanac of Liberty 135 (1954).

8 Although it has not been used in over a decade, at least one whipping post remains-in Delaware. See DEL. CODE ANN. tit. 11, §3908 (1953). A recent sentence under this statute is now under review by the Delaware Supreme Court. Phila. Evening Bulletin, Feb. 6, 1963, p. 3, col. 5 . See generally Caldwell, Red Hawnar (1947).

10 See People v. Blakeman, 170 Cal. App. 2d 596, 339 P.2d 202 (Dist. Ct. App. 1959); In re Newbern, 168 Cal. App. 2d 472, 335 P.2d 948 (Dist. Ct. App. 1959). The American Civil Liberties Union has recently protested the banishment of a number of juveniles from Wildwood, N.J. Civil Liberties, Feb. 1963, p. 3, col. 6.

11 See Foote, Vagrancy-Type Law and Its Administration, 104 U. PA. L. REv. 603 (1956).

12 E.g., In re Cammarata, 341 Mich. 528, 67 N.W.2d 677 (1954), cert. denied, 349 U.S. 953 (1955). 
in jurisdictions faced with immigration or racial problems, large welfare budgets, overpopulation, and the like..$^{13}$

\section{Definition and Purpose of Banishment}

Banishment has been defined as "a punishment inflicted upon criminals, by compelling them to quit a city, place, or country for a specified period of time, or for life. . . Synonymous with exilement and imports a compulsory loss of one's country." 14

Banishment for life need not be and in fact almost never has been imposed for crimes warranting life imprisonment. The person banished is usually guilty of a crime carrying a short prison sentence which will be imposed if he ever returns to the prohibited area. Banishment is not, therefore, primarily a penological device. It is most suitable as a means of effecting some other purpose.

In some cases, a convict's rehabilitation may indeed be furthered by sending him to a particular place where he is required to remain under local supervision for a specified time. ${ }^{15}$ This may be particularly true where the place to which he is sent is his home. In such a case, the banishment is to and not from a place; the purpose is rehabilitation rather than concession to politics and governmental laziness; the limitations on freedom are not permanent; and the condition is no more onerous than the usual parole restrictions on travel outside the supervisory control of the parole authorities. ${ }^{16}$ The convict is in exactly the same position as if under ordinary parole, with the single exception that he is in a location more conducive to his rehabilitation than the one where he happened to violate the law. ${ }^{17}$ The administration of justice would be furthered by even more extensive use of this sort of arrangement. ${ }^{18}$ The criticism leveled at banishment, therefore,

13 Banishment is also employed in East Germany, N.Y. Times, August 27, 1961, p. 1, col. 6; Soviet Russia, N.Y. Times, Feb. 6, 1962, p. 9, col. 6; Yugoslavia, N.Y. Times, May 10, 1962, p. 11, col. 2 ; and South Africa, Lowenstern, BrUTAl MANDATE 108 (1962); N.Y. Post, March 23, 1960, p. 2, col. 4. See generally SutherLand \& CRESSEy, op. cit. supra note 6, at 268; 3 HoldSworth, A History of ENGLISH Law 303 (5th ed. 1942) ; Navasky, Deportation as Punishment, 27 U. KAN. CITY L. Rev. 213 (1959); 32 N.C.L. REv. 221 (1954); Note, 5 UtAm L. Rev. 365 (1957).

14 BLACK, LAw Dictionary 183 (4th ed. 1951).

15 See Ex parte Ridley, 3 Okla. Crim. 350, 353, 106 Pac. 549, 550 (1910). The usual geographical restriction of a parole requires the parolee to remain within the jurisdiction. See, e.g., State v. McCray, 222 S.C. 391, 73 S.E.2d 1 (1952).

$16 \mathrm{~A}$ good example of intelligent conditions, reflecting these considerations, is Ex parte Nabors, 33 N.M. 324, 267 Pac. 58 (1928).

17 Interstate Compact for the Supervision of Parolees and Probationers, HandBOOK ON INTERSTATE CRIME CONTROL 56-82 (1955), has attempted to systemize this sort of parole on a national scale. Fach state agrees to accept parole responsibility for any offender whose residence in the state and potential employment there can be proven. The parolee is treated like all other parolees in that state but is subject to being recalled by the state in which he was sentenced. See 31 MINN. L. REv. 699 (1947) ; 21 AlBaNy L. REv. 327 (1957).

18 Cooperation under the compact is incomplete due mainly to excessively high residence and employment requirements. 
does not apply when sound criminological justifications exist for geographical restrictions on freedom. Criticism becomes appropriate when banishment is permanent and unsupervised. These elements will be included in the definition of banishment used in this Article.

Does banishment as thus defined serve any useful purpose? A system of penology will necessarily contain many elements that have undesirable features, but which are retained because of the overall benefit thought to be derived from them.

Rehabilitation and the consequent reduction of recidivism are presumably the prime objectives of modern penology. ${ }^{19}$ These goals are quite clearly frustrated, rather than furthered, by removing the individual to be rehabilitated from the control of the authorities who should be helping him. Severance from a corrupting environment may occasionally aid the reformation of a particular individual, ${ }^{20}$ but this can be accomplished by careful administration of selective limitations on freedom.

Actually, banishment does not further any of the other real or supposed penological ends. Crime will not be deterred by an ostensibly merciful sentence that is rarely invoked. The same considerations make the practice useless as a sop to the public's retributive impulses. Protection of the public from the individual offender is achieved only in the most parochial sense by foisting that offender on another jurisdiction. Finally, mercy, as an objective in the administration of criminal law, is most appropriately subsumed by considerations of rehabilitation; even if it were not, there is good reason to maintain that banishment as an alternative to imprisonment is not merciful at all, but is, on the contrary, so unmerciful as to be unconstitutional.

\section{BANISHMENT IN the COURTS}

\section{A. The Legal Rule}

Lower courts, virtually without exception, have been denied the right to impose banishment in connection with a criminal sentence. ${ }^{21}$

19 Glueck, Indeterminate Sentence and Parole in the Federal System: Some Comments on a Proposal, 21 B.U.L. Rev. 21, 23 (1941).

20 See Ex parte Hawkins, 61 Ark. 321, 325, 33 S.W. 106 (1895) (dictum); 30 Cotur. L. Rev. 1057 (1930).

21 People v. Blakeman, 170 Cal. App. 2d 596, 339 P.2d 202 (Dist. Ct. App. 1959); Ex parte Scarborough, 76 Cal. App. 2d 648, 173 P.2d 825 (Dist. Ct. App. 1946); People v. Lopez, 81 Cal. App. 199, 253 Pac. 169 (Dist. Ct. App. 1927); Hancock v. Rogers, $140 \mathrm{Ga}$. 688, 79 S.E. 558 (1913) ; Burnstein ex rel. Burnstein v. Jennings, 231 Iowa 1280, 4 N.W.2d 428 (1942); People v. Baum, 251 Mich. 187, 231 N.W. 95 (1930); Hoggett v. State, 101 Miss. 269, 57 So. 811 (1912); People v. Wallace, 124 N.Y.S.2d 201 (Suffolk County C. 1953); State v. Doughtie, 237 N.C. 368, 74 S.E.2d 922 (1953); State v. Baker, 58 S.C. 111, 36 S.E. 501 (1900); Ex parte Sheehan, 100 Mont. 244, 49 P.2d 438 (1935) (dictum). 
Banishment from neighborhood, ${ }^{22}$ town, ${ }^{23}$ county, ${ }^{24}$ state, ${ }^{25}$ or country ${ }^{26}$ are all proscribed, whether directly imposed, ${ }^{27}$ offered as an alternative to authorized punishment, ${ }^{28}$ or attached as a condition to probation. $^{29}$ Public policy reasons are given, most often focusing on one factor-interstate comity.

To permit one State to dump its convict criminals into another would entitle the State believing itself injured thereby to exercise its policies and military power in the interest of its own peace, safety, and welfare, to repel such an invasion. It would tend to incite dissension, provoke retaliation, and disturb that fundamental equality of political rights among the several States which is the basis of the Union itself. Such a method of punishment is not authorized by statute, and is impliedly prohibited by public policy. ${ }^{30}$

Although the courts have made other arguments against banishment, ${ }^{31}$ they generally limit their policy considerations to a quotation from the above passage or one like it. Nevertheless, underlying all of the decisions, is a strong feeling that, aside from the inter-jurisdictional strife it causes, banishment is inappropriate and undesirable as a punishment.

The closing words of the above quotation, however, contain a disturbing reservation that is found in most of the decisions. Courts apparently consider themselves barred from imposing a sentence of banishment only in the absence of affirmative legislative authority to do so. If public policy is the only available rationale for an attack on a sentence of banishment, a legislative authorization of banishment, specifically drafted in terms of public policy, would seem to foreclose judicial consideration of the matter. In an early Supreme Court opinion, Mr. Justice Cushing said, "The right to . . . banish, in the case of an offending citizen, must belong to every government. . . .

22 People v. Smith, 252 Mich. 4, 232 N.W. 397 (1930). 1946).

23 Ex parte Scarborough, 76 Cal. App. $2 d$ 648, 173 P.2d 825 (Dist. Ct. App.

24 Hancock v. Rogers, 140 Ga. 688, 79 S.E. 558 (1913) ; Hoggett v. State, 101 Miss. 269, 57 So. 811 (1912).

25 People v. Baum, 251 Mich. 187, 231 N.W. 95 (1930).

26 People v. Lopez, 81 Cal. App. 199, 253 Pac. 169 (Dist. Ct. App. 1927).

27 State v. Baker, 58 S.C. 111, 36 S.E. 501 (1900).

28 People v. Wallace, 124 N.Y.S.2d 201 (Suffolk County Ct. 1953).

29 People v. Baum, 251 Mich. 187, 231 N.W. 95 (1930).

30 Id. at 189,231 N.W. at 96.

31 Chief among these arguments is lack of statutory authority. Cf. Millsaps v. Strauss, 208 Ark. 265, 185 S.W.2d 933 (1945). Other arguments advanced are the inability of a court to suspend sentence indefinitely in the absence of a statute, Shondell $v$. Bradley, 42 Ohio App. 8, 181 N.E. 559 (1931), and the illegality of alternative sentences, State v. Hatley, 110 N.C. 522,14 S.E. 751 (1892) (dictum). 
[I]t naturally, as well as tacitly, belongs to the legislature." 32 However, because legislation authorizing banishment as a sentence has never been passed, ${ }^{33}$ an assertion of legislative authority has not actually been tested. But modern banishment cases often contain dictum indicating that such legislation would survive judicial attack. ${ }^{34}$

\section{B. Actual Court Practice}

Even in the absence of enabling legislation, and despite the contrary judicial authority, some lower courts do impose banishment as a sentence. ${ }^{35}$ A California trial judge imposed the following sentence upon a vagrant charged with public drunkenness:
"This document I have just signed is an order directing the Chief of Police to commit you to jail for a period of 180 days. However, there will be a five-day stay of execution in this matter, which means that you will be released now to get out of this state. This court warns you, however, that you had better get out of this state and stay out. You will be a fugitive from Justice, and while we will not extradite you from any other state on this, if you ever again set foot in the state of California, you are going to spend 180 days in jail just as surely as your name is Emery Newbern." 36

The appellate court, although holding the conviction void on another ground, said that notwithstanding the policy against banishment, this sentence was technically unimpeachable on that ground; the lower court had not imposed banishment, but had merely afforded the opportunity for an illegal departure. ${ }^{37}$

The California trial court's ingenuity is unusual but its approach to the problem of vagrancy is not. "[I]n spite of the revulsion which liberty-loving people have long had against banishment, it lingers on in many magistrate courts. . . . Scores of people are thus banished from our cities every day." 38 Lower courts, faced with pressing local problems, little public scrutiny, and the unlikelihood of appeal, have

32 Cooper v. Telfair, 4 U.S. (4 Dall.) 14, 18 (1800).

33 Cooper v. Telfair, supra note 32 , involved a statute authorizing banishment in that it was a bill of attainder specifically banishing the defendant by name. The Court at this early date doubted its own power to invalidate such a statute as unconstitutional. Id. at 19 (Chase, J.). See Note, 5 UTAZ L. REv. 365, 367 (1957).

34 See, e.g., Ex parte Sheehan, 100 Mont. 244, 49 P.2d 438 (1935).

35 See, for example, the procedure employed in State v. McAfee, 189 N.C. 320, 127 S.E. 204 (1925); In re Hinson, 156 N.C. 250,72 S.E. 310 (1911); State v. Hatley, 110 N.C. 522,14 S.E. 751 (1892). 1959).

${ }^{36}$ In re Newbern, 168 Cal. App. 2d 472, 475, 335 P.2d 948, 950 (Dist. Ct. App.

37 Id. at 476,335 P.2d at 951.

38 Douglas, Vagrancy and Arrest on Suspicion, 70 Y ALE L.J. 1, 2 (1960). For recent incidents involving juvenile offenders, see Civil Liberties, Feb. 1963, p. 3, col. 3. 
regularly seen fit simply to ignore appellate rulings on the subject. A standard modus operandi has been developed which relies heavily on a type of banishment.

We are advised by counsel for respondent that in sentencing the prisoner in the manner above related, the trial judge was but following an established routine or custom. If that be true the custom is not founded in law but is based solely upon someone's arbitrary view as to how offenders against an ordinance such as the one involved here should be punished. ${ }^{30}$

The local patrolman will, and indeed must, always be able to effect an on the spot "banishment" by simply ordering an undesirable to "move on." When, however, matters reach the magistrate's courtroom, two new elements are added-the offender must leave the entire jurisdiction, and a prison sentence is held over his head to discourage his return.

It has been said that since vagrants are arrested for being something rather than for doing something, and are charged with a condition rather than a crime, the vagrancy laws should be thought of as preventive rather then punitive.40 This view, however, has been vigorously denounced as "an echo from an ancient position that has almost entirely disappeared at the present time." 41 It would indeed seem unthinkable to allow such a distinction to exempt vagrancy procedures from basic criminal safeguards when under such procedures a man can receive up to two years in prison.

There are practically no regular procedures in "mass production" vagrancy trials. They seem to represent the worst sort of amalgam of police informality and judicial authority, ${ }^{22}$ and sentences of banishment are handed down in the same informal manner that characterizes the entire proceedings. A tramp, saved from a prison term only by producing a bus ticket, is told: "You better get on that bus quick . . . because if you're picked up between here and the station, you're a dead duck." " 43 The tramp sprints for the bus station, and the community is freed from the problem created by his presence. In this way, large numbers of such undesirables are ejected rather than dealt with by 1959).

39 In re Newbern, 168 Cal. App. 2d 472, 476, 335 P.2d 948, 951 (Dist. Ct. App.

40 See People v. Belcasto, 356 Ill. 144, 148, 190 N.E. 301, 303 (1934); Lacey, Vagrancy and Other Crimes of Personal Condition, 66 HARv. L. REv. 1203 (1953).

41 Perkins, The Vagrancy Concept, 9 Hastings L.J. 237, 251 (1958).

42 Vagrancy proceedings are examined at length in Foote, Vagrancy-Type Law and Its Administration, 104 U. PA. L. REv. 603 (1956). The article was based upon stenographic notes taken by the author's agents who observed hundreds of vagrancy "trials." Official transcripts are almost never taken in such proceedings. See Douglas, supra note 38 .

13 Foote, supra note 42 , at 605 . 
the community. Other communities handle the problem similarly, and a large mass of transient "floaters" is created by an illegal banishment procedure that solves the problems of no one except the politicians and crusading newspapers who find it profitable to raise a periodic furor about "clearing the bums off the streets."

Considering the tremendous problems involved in dealing with vagrants, some slipshod administration is unavoidable. The volume of cases is fantastic ; ${ }^{44}$ public prejudice is often very high; and magistrates usually lack adequate probation facilities and the power to utilize those that exist. Even appellate courts are inclined to find procedural niceties less compelling than the oft quoted view of one judge: "Society recognizes that vagrancy is a parasitic disease which, if allowed to spread, will sap the life of that upon which it feeds." 45

Perhaps the judge was accurate in describing the vagrancy problem in terms of disease rather than crime. ${ }^{46}$ But this does not justify resort to an illegal remedy. If the alternative of banishment can be eliminated, communities that are no longer able to duck the problem of vagrancy may be moved to deal with it. ${ }^{47}$

\section{Banishment and the Pardon Power}

Judicial declarations invalidating banishment by courts do not purport to apply to executive pardon. The modern pardon power has been held to be analogous to that of the Kings of England and, therefore, almost absolute. ${ }^{48}$ Public policy places no limitations on the executive, who is usually not even required to state the reasons for his actions much less to justify them. ${ }^{49}$ Consequently, although banishment is uniformly condemned when connected with a judicial sentence, it is upheld with equal unanimity when attached as a condition to executive pardon. ${ }^{50}$

$44 \mathrm{It}$ is not uncommon for a magistrate to deal with fifty or sixty defendants in less than a quarter of an hour. One magistrate was found to handle 1,600 cases a month. Id. at 605-07.

46 State v. Harlowe, 174 Wash. 227, 233, 24 P.2d 601, 603 (1933).

46 Historically, the problem has not usually been considered a criminal one. See Foote, supra note 42, at 615, 616; Geeson, The Justices, the Vagrants and the Poor, 112 JUSTICE OF TRE PEACE AND LoCAL GOVERNMENT ReV. 289 (1948).

47 Removal statutes, whereby a state rids itself of out-of-staters who are on the relief rolls, have been held constitutional. In the Matter of Chirillo, 283 N.Y. 417, 28 N.E.2d 895 (1940). They have been considered non-penal attempts to place the expense of supporting an indigent on his home state.

48 Vanilla v. Moran, 188 Misc. 325, 333, 67 N.Y.S.2d 833, 841 (Sup. Ct.), aff'd, 272 App. Div. 859, 70 N.Y.S.2d 613 (1947), aff'd, 298 N.Y. 796, 83 N.E.2d 696 (1949).

48 "Often the reasons for pardons have been absurd and ridiculous. One governor remitted $a$ death sentence because "hanging would do the man no good . . . ." Stoke, A Review of the Pardon Power, 16 Ky. L.J. 34, 36 (1927).

50 Cooper v. Telfair, 4 U.S. (4 Dall.) 14 (1800); Kavalin v. White, 44 F.2d 49 (10th Cir. 1930); Ex parte Hawkins, 61 Ark. 321, 33 S.W. 106 (1895); Ex parte 
The right to attach conditions to a pardon is occasionally based on the language in a constitutional grant, ${ }^{51}$ but a simple grant of power to pardon is adequate and more common. ${ }^{2}$ A condition may be precedent, in which case suspension of the sentence does not take place until compliance; or subsequent, whereby the suspension is revoked if the condition is violated. ${ }^{53}$ Various types of conditions may be imposedgood behavior, ${ }^{54}$ a duty to report, a requirement of enlistment, ${ }^{55}$ a curfew, sobriety, or banishment. Finally, a condition can remain in effect beyond the expiration of the original sentence, so that a man may be subject to it for the rest of his life. ${ }^{56}$ If the condition is violated, the sentence may be automatically reimposed, without a hearing. ${ }^{57}$

\section{A. The Illegal, Immoral, or Impossible Condition}

There is one limitation on the pardon power, but it is seldom invoked. A condition must not be "illegal, immoral or impossible of performance." 58 A condition is not illegal, however, unless expressly prohibited by law. ${ }^{59}$ Conditions have actually been upheld where statutory or constitutional requirements were ignored or contra-

Marks, 64 Cal. 29, 28 Pac. 109 (1883) ; Pippin v. Johnson, $192 \mathrm{Ga} .450,15$ S.E.2d 712 (1941); State ex rel. O'Connor v. Wolfer, 53 Minn. 135, 54 N.W. 1065 (1893); Ex parte Strauss, 320 Mo. 349, 7 S.W.2d 1000 (1928); cf. In re Cammarata, 341 Mich. 528, 67 N.W.2d 677 (1954); People v. Potter, 1 Parker, Cr. R. 47, 1 Edm. Sel. Cas. 235 (N.Y. Sup. Ct 1846) ; Ex parte Lockhart, 12 Ohio Dec Reprint 515 (Super. Ct. 1855) ; Ex parte Snyder, 81 Okla. Crim. 34, 159 P.2d 752 (1945); Ex parte Sherman, 81 Okla Crim 41, 159 P.2d 755 (1945); Commonwealth v. Haggerty, 4 Brewster 326 (Phila., Pa. County Ct. 1869); Flavell's Case, 8 W. \& S. 197 (Pa. 1844); State v. Barnes, 32 S.C. 14, 10 S.E. 611 (1890); State v. Fuller, 1 McCord 178 (S.C. 1821) ; State v. Smith, 1 Bailey 283 (S.C. 1829).

51 See Ex parte Lockhart, 12 Ohio Dec. Reprint 515 (Super. Ct. 1855).

62 See U.S. Const. art. II, §2; Vitale v. Hunter, 206 F.2d 826 (10th Cir. 1953).

53 This distinction is basic in the rare case where a court holds a pardon condition to be void. If the condition was "subsequent," the pardon becomes absolute. Taylor v. State, 41 Tex. Crim. 148, 51 S.W. 1106 (1899). See 12 Minn. L. REv. 291-93 (1928). However, in People v. Blakeman, 170 Cal. App. 2d 596, 339 P.2d 202 (Dist. Ct. App. 1959), the court did not bother with such distinctions and simply held that a condition of banishment was separable from the pardon to which it is attached. The individual was entitled to his freedom when the condition was voided.

54 State ex rel. Brown v. Mayo, 126 Fla. 811, 171 So. 822 (1937).

55 Huff v. Aldredge, $192 \mathrm{Ga}, 12,14$ S.E.2d 456 (1941) (enlist in CCC); Ex parte Brown, 243 S.W.2d 167 (Tex. Crim. App. 1951) (enlist in Army).

56 Harrell v. Mount, 193 Ga. 818, 20 S.E.2d 69 (1942).

57 Muckle v. Clarke, 191 Ga. 202, 12 S.E.2d 339 (1940); Ex parte Snyder, 81 Okla. Crim. 34, 159 P.2d 752 (1945); Escoe v. Zerbst, 295 UU.S. 490, 492-93 (1935) (dictum). But see Fleenor v. Hammond, 116 F.2d 982 (6th Cir. 1941); Weihofen, Revoking Probation, Parole or Pardon Without a Hearing, 32 J. CRIM. L. \& CRIMINOLOGY 531 (1942); Note, 65 Harv. L. Rev. 309 (1951); 28 So. Cal. L. Rev. 158 (1955). This may be true even if the punishment is death and the death penalty is abolished prior to the breach of the pardon condition. State v. Addington, 2 Bailey 516 (S.C. 1831).

58 In re McKinney, 33 Del. 434, 436, 138 At1. 649, 650 (1927).

59 State v. Barnes, 32 S.C. 14, 10 S.E. 611 (1890). 
vened. ${ }^{60}$ The requirement that a condition not be immoral seems to be used only as a makeweight. Even the impossibility of a condition has not always proved fatal. ${ }^{61}$

Some courts have stated a broader rule. "[The condition must be] consistent with justice, and neither opposed to public policy [n]or the law of the land." ${ }^{22}$ However, statements of limitation of any sort are invariably made in opinions upholding a condition; few cases can be found in which a condition actually was invalidated. ${ }^{83}$

Courts have almost always found a condition of banishment to be legal, moral, and possible of performance, even in cases where the state constitution contained a provision outlawing banishment specifically. ${ }^{64}$ The only case squarely holding a condition of banishment void ${ }^{65}$ was subsequently disapproved. ${ }^{66}$ It has even been held that a state has power to banish from the country. In an early New York case, a man serving five years for grand larceny was pardoned on such a condition. When he was subsequently discovered in Louisiana, it was held that his presence there revoked his pardon. ${ }^{67}$

Once in a great while, a court may modify the rigors of a particular banishment order under the press of appealing circumstances. ${ }^{68}$ The usual attitude, however, has been one of extreme rigidity, exemplified by the case of a woman who returned to a state from which she had been banished because she needed medical attention in order to save her life. She was discovered, her sentence was reimposed, and she was returned to prison. ${ }^{69}$

60 Ex parte Wells, 59 U.S. (18 How.) 307 (1855) ; Baston v. Robbins, $153 \mathrm{Me}$. 128,135 A.2d 279 (1957).

61 State v. Fuller, 1 McCord 178 (S.C. 1821).

62 Ex parte Lockhart, 12 Ohio Dec. Reprint 515, 516 (Super. Ct. 1855).

63 But see Logan v. People, 138 Colo. 304, 332 P.2d 897 (1958) (furnish appearance bond); In re McKinney, 33 Del. 434, 138 Atl. 649 (1927) (pardon revocable by probation official); State ex rel. Davis v. Hunter, 124 Iowa 569, 100 N.W. 510 (1904) (forfeit good-time allowance); Commonwealth y. Fowler, 8 Va. (4 Call) 35 (1785) (work three years as public official directs).

04 Ex parte Snyder, 81 Okla. Crim. 34, 159 P.2d 752 (1945).

65 Commonwealth v. Hatsfield, 2 Pa. L.J. Rep. 32 (Berks County Oyer \& Terminer 1842).

66 Commonwealth v. Haggerty, 4 Brewster 326 (Phila., Pa. County Ct. 1869). In this case, Commonwealth v. Fowler, $8 \mathrm{Va}$. (4 Call) 35 (1785) and $E_{x}$ parte Amour Hunt, 10 Ark. (5 English) 284 (1850), upon which the Hatsficld opinion had relied, were both successfully distinguished.

o7 People v. Potter, 1 Parker, Cr. R. 47, 1 Edm. Sel. Cas. 235 (N.Y. Sup. Ct. 1846); accord, In re Cammarata, 341 Mich. 528, 67 N.W.2d 677 (1954).

68 People v. James, 2 Cai. R. 57 (N.Y. Sup. Ct. 1804) (offender granted an additional forty days to leave the country upon showing that insanity had prevented his timely departure).

60 Pippin v. Johnson, 192 Ga. 450, 15 S.E.2d 712 (1941). 


\section{B. The Historical Argument for Banishment by Pardon}

Opinions upholding banishment by pardon usually are prefaced by some reference to the historical background of the pardon power, particularly as practiced in England.

As this power had been exercised, from time immemorial, by the executive of that nation whose language is our language, and to whose judicial institutions ours bears a close resemblance; we adopt their principles respecting the operation and effect of a pardon, and look into their books for the rules prescribing the manner in which it is to be used .... ${ }^{\text {ro }}$

Under common law, pardon was a peculiarly royal prerogative which had to be granted under the Great Seal. ${ }^{71}$ The King's pardon power was extremely broad, and his right to impose conditions was unquestioned. $^{72}$ That power still represented a kingly manifestation of mercy when transplanted to the colonies to be exercised by the royal governors. After the Revolution, fear of a strong executive caused many states to vest the pardon power in the legislature. ${ }^{73}$ The later move back to the executive was followed by a further shift of power to parole boards. ${ }^{74}$ All of this would seem to indicate the importance of indigenous factors rather than the relevance of the English experience. It would seem more appropriate to relate banishment to modern values than to historical ones which to a large extent have been discredited. An appeal to history can never be more than an introduction intended to lend weight to a position that has supposedly survived through history for other reasons.

\section{Banishment as a Merciful Act of Grace}

Although the notion would seem more appropriate in a monarchistic society than in ours, American judges still maintain, as did $\mathrm{Mr}$. Chief Justice Marshall in 1833, that the granting of a pardon is a merciful "act of grace" to which a sovereign may attach any condition

70 United States v. Wilson, 32 U.S. (7 Pet.) 149, 159-60 (1833).

71 See Brett, Conditional Pardons and the Commutation of Death Sentences, 20 MODERN L. REv. 131, 132 (1957).

72 For a more complete history of the pardon power see JENSEN, PARDoning Power IN THE AMERICAN States 1-8 (1922); Brett, supra note 71; Lattin, The Pardoning Power in Massachusetts, 11 B.U.L. REv. 505 (1931); Weihofen, Consolidation of Pardon and Parole: $A$ Wrong Approach, $30 \mathrm{~J}$. Cras. L. \& CrImINology 534 (1939).

73 See Jensen, op. cit. supra note 72, at 9; Sutherdand \& Cressey, Principles of CrIminology 545 (6th ed. 1960).

74 See id. at 269; 13 VA. L. REv. 245 (1927). 
it chooses." "Nor is there any substance in the contention that there is any substantial difference in this matter between the executive power of pardon in our Government and the King's prerogative." 78

Mercy and acts of grace should have no place at all in a system that dispenses adequate justice initially and which maintains appropriate machinery for the handling and release of convicts in accordance with modern penological standards. In the hands of an overworked executive, the pardon power is too often subject to political, emotional, and other irrelevant influences. A New York governor claimed that a second chief executive was needed to handle nothing but pardons. ${ }^{77}$ Beccaria wrote:

Happy the nations in which [pardons] . . . will be considered as dangerous! Clemency, which has often been deemed a sufficient substitute for every other virtue in sovereigns, should be excluded in a perfect legislation, where punishments are mild, and the proceedings in criminal cases regular and expeditious. ${ }^{78}$

Montesquieu, Kant, Bentham, and others concurred in this opinion. ${ }^{79}$

The fact is that the machinery of justice is not yet so perfect that mercy cannot occasionally serve as an important $\operatorname{cog} .^{80}$ However, that $\operatorname{cog}$ must mesh with the system of which it is a part.

A pardon in our days is not a private act of grace from an
individual happening to possess power. It is a part of the
Constitutional scheme. When granted, it is the determina-
tion of the ultimate authority that the public welfare will be
better served by inflicting less than what the judgment fixed.

As a "part of the constitutional scheme" the pardon would seem subject to constitutional limitations, particularly with respect to a function like the annexing of conditions, where the elements of "mercy" and "grace" are really not relevant at all. The pardon itself might be con-

75 United States v. Wilson, 32 U.S. (7 Pet.) 149, 160 (1833).

76 Ex parte Grossman, 267 U.S. 87, 113 (1925).

77 SutherLAND \& Cressey, op. cit. supra note 73, at 546.

78 Beccaria, An Essay on Crimes and Punishments 134 (1807).

79 JENSEN, op. cit. supra note 72, at 23-29; Weihofen, Pardon: An Extraordinary Remedy, 12 Rocky Mt. L. Rev. 112, 113 (1940) ; cf. Glueck, Probation and CrinsiNAI JUSTICE 109-11 (1933).

80 Restrictions on parole make the need for mercy particularly real as in jurisdictions where parole is unavailable in life sentences. Note, A Survey of the Law of Probation and Parole in Pemsylvania, 30 TEMP. L.Q. 309 (1957). See also Weihofen, supra note 72, at 537.

81 Biddle v. Perovich, 274 U.S. 480, 486 (1927) ; accord, 3 Attorney General's Survey of Release Procedures 195 (1939); Weihofen, Revoking Probation, Parole or Pardon Without a Hearing, 32 J. CRIM. L. \& CRIMINology 531, 534 (1942); Note, 65 Harv. L. Rev. 309 (1951); Comment, 28 So. Cal. L. Rev. 158 (1955). 
sidered to be an act of mercy but a condition annexed thereto is most assuredly not. Complete mercy would result in complete pardon, and if a condition is imposed to limit that pardon its merciful qualities must spring from something other than the mercy it serves to diminish.

\section{Judicial Review of Banishment by Pardon: A Problem of Separation of Powers}

Another fallacy which shields banishment by pardon from proper scrutiny is the notion that the doctrine of separation of powers bars any sort of judicial review.

Executive clemency exists to afford relief from undue harshness or evident mistake in the operation or enforcement of the criminal law . . . . [I]t has always been thought essential in popular governments, as well as in monarchies, to vest in some other authority than the courts power to ameliorate or avoid particular criminal judgments. ${ }^{82}$

According to this theory, the executive is given an absolute check on injustices in the other two branches of government. To preserve the effectiveness of that check, the courts must be denied the power to review the executive's action. The only remedy for abuse is through the improbable, and to the convict, the highly irrelevant counter-check of impeachment. "Even for the grossest abuse of this discretionary power vested in the Governor the law affords no remedy. The courts have no concern with the reasons which actuate the Executive. The discretion exercised by him . . . is beyond the control or legitimate criticism of the judiciary." "83 Conditional pardons, therefore, are upheld on the specific ground that the greater power of complete pardon necessarily includes the lesser power of conditional pardon. A court's power to review both is equally limited. ${ }^{84}$

A condition, however, is not really a part of the pardon to which it is attached; rather, it detracts from the merciful quality which immunizes the pardon from review. The validity of the power to place limitations on a pardon should depend upon factors relevant to that power, and not upon the totally unrelated purposes behind the pardon itself. If a condition is oppressive, particularly if speciously attractive when imposed, the purpose of protecting the convict from harsh application of the law is subverted by a court's refusal to interfere. In such

82 Ex parte Grossman, 267 U.S. 87, 120-21 (1925).

83 Ex parte Snyder, 81 Okla. Crim. 34, 38, 159 P.2d 752, 754 (1945), quoting Ex parte Edwards, 78 Okla. Crim. 213, 219, 146 P.2d 311, 314 (1944); see 11 CoRNEI.L L.Q. 528, 529 (1926).

84 Ex parte Lockhart, 12 Ohio Dec. Reprint 515, 516 (Super. Ct. 1855). 
a case, harshness enanates from the very executive whose immunity from review is supposed to check harshness, and the assumption that a pardon is always merciful and never, in any way, detrimental to the convict is no longer true. The fact that an act of executive "clemency" is involved should not alter the importance of insuring that "those who inflict a deprivation of liberty are not the final arbiters of its legality." 85

\section{E. The Contract Theory}

The most common justification for banishment by pardon is based on the undeniable fact that, unlike Romeo, the convict often embraces his fate quite eagerly. Caveat emptor as applied to hardened criminals seems only too appropriate, and the guarantees and legal rules that would normally attach to this peculiarly criminal area are put aside because somehow the issue has become contractual. So forceful is the effect of this transmutation that it is the favorite means whereby courts evade specific constitutional bans on banishment; they are interpreted as being inapplicable in a voluntary, contractual setting. ${ }^{80}$ As one court expressed it, "[T] word, ['grant' of pardon] the idea that the minds of both parties to the instrument have met, that they have agreed that one shall execute and deliver, and the other shall accept and receive." 87

Mr. Chief Justice Marshall stated that "A pardon is a deed, to the validity of which, delivery is essential, and delivery is not complete, without acceptance." 88 In dictum in the same case, the Chief Justice went on to postulate what appeared to be a key assumption in the analogy. "It [the pardon] may then be rejected by the person to whom it is tendered; and if it be rejected, we have discovered no power in a court to force it on him." ${ }^{89}$ However, when a case finally arose where a convict actually insisted on his right to refuse a pardon, Mr. Justice Holmes said: "Just as the original punishment would be imposed without regard to the prisoner's consent and in the teeth of his will, whether he liked it or not, the public welfare, not his consent, determines what shall be done." 90 Thus, the contract may be imposed upon the convict

85 Shachtman v. Dulles, 225 F.2d 938, 944 (D.C. Cir. 1955) (concurring opinion). 86 Ex parte Lockhart, 12 Ohio Dec. Reprint 515, 516 (Super. Ct. 1855).

87 People v. Potter, 1 Parker, Cr. R. 47, 51, 1 Edm. Sel. Cas. 235, 240 (N.Y. Sup. Ct. 1846).

88 United States v. Wilson, 32 U.S. (7 Pet.) 149, 160 (1833).

89 Ibid.

90 Biddle v. Perovich, 274 U.S. 480,486 (1927). In this case a death penalty was commuted to life imprisonment. For procedural reasons the convict sought to maintain that his lack of consent voided the pardon. Similar results were reached in a parole context in Gould v. Taylor, $153 \mathrm{~F}$. Supp. 71 (M.D. $\mathrm{Pa} .1957$ ), and in Singleton v. Looney, 218 F.2d 526 (10th Cir. 1955). Contra, In re Peterson, 14 Cal. $2 \mathrm{~d} 82,92$ P.2d 890 (1939), where a convict was allowed to refuse parole to 
against his will and, if arguments involving the executive act of grace and the separation of powers are accepted in their entirety, there is no legal compulsion at all for the executive to keep his side of the already one-sided bargain. There is, of course, no real bargaining between a convict and his sovereign-the terms are not arrived at bilaterally, the parties are in no sense equal, and there is agreement only in the sense that the convict finds the situation temporarily agreeable. Even if the form of the transaction is conceded to be of some significance, what we have here is a strange sort of contract from which to draw rigorous analogies. ${ }^{01}$

In truth, the form is entirely irrelevant. The grant by the executive is itself the event that gives life to the pardon. Acceptance by the convict only aids in determining whether or not the grant will be made. ${ }^{92}$ To suppose that a matter involving both the public welfare and the life and freedom of an individual should be decided by reference to the laws of the market place would be preposterous were it not for the illustrious authority that can be cited for the proposition. ${ }^{93}$ If the convict has rights with respect to the conditions of his pardon, they are not the result of a contract with the executive, but of the laws and constitutional provisions pertinent to the administration of criminal justice. "Indeed, it is only in a somewhat fictitious sense that a conditional pardon is spoken of as a contract. It is, as a matter of fact, simply the grant and acceptance of a privilege, with a condition attached, in accordance with which the privilege may be revoked." 94

The peculiar dichotomy arrived at by the courts with respect to banishment by sentence and banishment by pardon highlights the absurdity of the contract theory. Can a governor's conditional pardon be justified as being contractual when a judge cannot make the same contract with a probationer? ${ }^{95}$

another state where he was wanted for a more serious crime. Commentators generally agree with the holding in Biddle. See 3 AtroRNEY GENERAL's SuRvey of REIEASE Procedures 180 (1939); 41 OPS. ATT'Y GEN., No. 37 (1955); Weihofen, supra note 81 . Contra, Brett, supra note 72 .

91 Other contractual concepts that have been applied in pardon situations are estoppel, In re Cammarata, 341 Mich. 528, 67 N.W.2d 677 (1954), and fraud, Ex parte Marks, 64 Cal. 29, 28 Pac. 109 (1883).

92 Some jurisdictions label a condition without consent a "commutation" and require specific statutory authority for its exercise. Ex parte Lefors, $165 \mathrm{Tex}$ Crim. 51, 303 S.W.2d 394 (1957). In a few jurisdictions, consent is statutorily required. E.g., OHIO REv. CODE ANN. \$2965.10 (Page 1954) (must accept pardon); W. VA. CodE ANs. \$250 (1961) (must accept any condition imposed).

Q3 Marshall's dictum in Wilson has been vigorously attacked on its own terms. "No such rule is laid down by the English authorities. On the contrary . . - the convict was not permitted to waive [a pardon]." 3 ATIORNEY GENERAL's Survey OF RELEASE PROCEDURES 180 (1939).

OA State ex rel. Davis v. Hunter, 124 Iowa 569, 574, 100 N.W. 510, 512 (1904).

95 $\mathrm{A}$ distinction can conceivably be made if probation is thought of as in no way constituting punishment. 11 B.U.L. REv. 278 (1931). The situation with respect to parole is illustrated by Gould v. Taylor, 153 F. Supp. 71 (M.D. Pa. 1957); Singleton v. Looney, 218 F.2d 526 (10th Cir. 1955). 
Rejecting the contention that the defendant had waived the right to challenge his banishment because he had suggested it in the first place and benefited by the resulting probation, a California court said:

The fallacy of this argument is that we are not dealing with a right or privilege conferred by law upon the litigant for his sole personal benefit. We are concerned with a principle of fundamental public policy. The law cannot suffer the state's interest and concern in the observance and enforcement of this policy to be thwarted through the guise of waiver of a personal right by an individual..$^{96}$

The irrelevance of the law of contracts to the conditions imposed on a pardon is particularly manifest when a condition is attacked on grounds of cruelty. It would seem quite clear that a sadistic governor cannot exchange twenty years of freedom for a pound of flesh, regardless of the wishes of the convict in question.

\section{Constitutional Theories of Attack}

The most effective way to remove the practice and threat of banishment would be to find a constitutional basis on which it might be attacked. Sentencing judges would find it difficult to evade or ignore a clear holding of unconstitutionality. Legislatures could not contradict it, and executive imposition of banishment by pardon, if not illegal under the traditional pardon limitations, would be invalidated as being unconstitutional.

\section{A. The Right To Travel}

One constitutional right that has been mentioned in most comments on banishment and elaborated on at length in some ${ }^{97}$. is the right to travel. If the Constitution grants a citizen of the United States the unqualified right to travel freely, limiting that freedom would seem unconstitutional.

Relying on an 1868 Supreme Court decision, ${ }^{98} \mathrm{Mr}$. Justice Douglas, in a concurring opinion in Edwards v. California, ${ }^{89}$ disagreed with the majority holding that a California anti-migrant statute violated only the commerce clause of the Constitution:

I am of the opinion that the right of persons to move freely from State to State occupies a more protected position in

86 People v. Blakeman, 170 Cal. App. 2d 596, 598, 339 P.2d 202, 203 (1959).

97 See Bowman, The United States Citizen's Privilege of State Residence, 10 B.U.L. REv. 459 (1930); 11 B.U.L. REv. 278, 279 (1931); Note, 5 UTaE L. Rev. 365,374 (1957).

98 Crandall v. Nevada, 73 U.S. (6 Wall.) 35 (1868).

99314 U.S. 160, 177 (1941) (concurring opinion). 
our constitutional system than does the movement of cattle, fruit, steel and coal across state lines. . . . The right to move freely from State to State is an incident of national citizenship protected by the privileges and immunities clause of the Fourteenth Amendment against state interference. ${ }^{100}$

This argument, however, may go too far. Of chief concern is the possible effect of such a doctrine on useful restrictions analogous to parole. For instance, the administration of the Interstate Compact ${ }^{101}$ might be affected. Any program limiting the right to travel would seem to be jeopardized regardless of penological considerations. If an attempt were made to protect the parole system on the ground that the right to travel is no more applicable to a parolee than to an imprisoned convict, the same reasoning could be applied to a banished convict. Problems of this sort arise because the factors that differentiate objectionable banishment from worthwhile penological devices are not translatable in terms of a right to travel.

\section{B. Due Process}

Professor Chafee had considerable difficulty with Justice Douglas' position. With respect to anti-migrant legislation, he preferred reliance on the due process clause.
Already in several decisions the Court has used the Due Process Clause to safeguard the right of the members of any race to reside where they please inside a state, regardless of ordinances and injunctions. Why is not this clause equally available to assure the right to live in any state one desires? .. Thus the "liberty" of all human beings which cannot be taken away without due process of law includes . . . liberty of movement. ${ }^{102}$

This approach is a variant of the right-to-travel argument. Whether or not it solves the problem of anti-migrant laws, it is not useful in dealing with banishment, a strictly penological problem. What is needed is a constitutional doctrine that addresses itself to penological factors.

\section{Banishment : Cruel and Unusual Punishment}

The guarantee against cruel and unusual punishment is a constitutional provision framed directly in terms of penological considera-

$100 \mathrm{Ibid}$. See also Kent v. Dulles, 357 U.S. 116, 125 (1958); Note, The Right To Travel, 6 NATURAL L.F. 109 (1961).

101 Interstate Compact for the Supervision of Parolees and Probationers, HANDbook on Interstate Crime Control 56-82 (1955); See note 17 supra. (1956).

102 Chafee, Three Human Rights in the Constitution of 1787, at 192-93 
tions. This provision is applicable to the states, ${ }^{103}$ most of which have an analogous prohibition in their own constitutions. ${ }^{104}$ If it can be shown that the eighth amendment proscribes banishment, it may serve not only to strengthen the fourteenth amendment due process argument by grounding it upon a more relevant right, but also may render banishment vulnerable to state constitutional objections. ${ }^{105}$ The difficulties encountered in relying on a right to travel are avoided because all considerations relevant to a right specifically concerned with punishment are necessarily within a penological framework. Those forms of expulsion that meet valid penological criteria would not be cruel and, therefore, not proscribed.

The historic roots of the ban against cruel and unusual punishment can be traced back to 1042 during the reign of Edward the Confessor. ${ }^{106}$ The ban was reformulated in the Magna Charta, ${ }^{107}$ and, after the atrocities of the Tudor and Stuart periods, was embodied in the Declaration of Rights of $1688 .{ }^{108}$ The prohibition was transposed almost directly from that Declaration to the United States Constitution. ${ }^{109}$ Similar provisions can be found in colonial laws as early as 1641 and are now in effect in most of the states. ${ }^{110}$

\section{A. The Historical Interpretation}

Judicial discussions of a cruel and unusual punishment clause almost always begin with an apologetic statement that the concept has never been adequately defined. ${ }^{111}$ Some courts then try to define it in meaningful, modern terms, but many merely enumerate a few of the horrors-drawing and quartering, dragging, crucifixion, disembowelling-to which that ban was directed in the seventeenth century. ${ }^{112}$ They are satisfied to point out that no such behavior exists today.

103 Although there has been some confusion as to whether or not the cruel and unusual punishment ban is incorporated in the fourteenth amendment, recent Supreme Court decisions seem to settle the fact that it is. Robinson v. California, 370 U.S. 660 (1962); Louisiana ex rel. Francis v. Resweber, 329 U.S. 459, 463 (1947) ; see Sutherland, Due Process and Cruel Punishment, 64 HARv. L. REv. 271 (1950).

104 Of the first forty-eight states, only Vermont and Connecticut do not have explicit provisions. Decisions indicate that the ban is assumed to exist by implication in those jurisdictions. 34 MINN. L. REV. 134, 136 (1950). The constitutions of Alaska (art. I \& 12) and Hawaii (art. I \$9) contain explicit provisions.

105 In a few states, however, it is not clear that the cruel and unusual punishment ban is binding upon the legislature. See Kirschgessner v. State, 174 Md. 195, 198 Atl. 271 (1938).

108 Note, 4 VAND. L. Rev. 680, 682 (1951).

107 Magna Charta, cl. 20.

1081 W. \& M. 2, c. 2.

1082 Story, Commentaries on the Constitution $\$ 1903$ (4th ed. 1873).

110 See note 104 supra.

111 E.g., Trop v. Dulles, 356 U.S. 86, 99 (1958).

112 E.g., Wilkerson v. Utah, 99 U.S. 130, 135-36 (1878). 
Story flatly stated that "the provision would seem to be wholly unnecessary in a free government, since it is scarcely possible that any department of such a government should authorize or justify such atrocious conduct." 118

Most courts that espouse the historical approach do not follow their premise to such an ultimate conclusion. They merely state that the prohibition applies only to "such . . . cruel and unusual punishments as disgraced the civilization of former ages, and made one shudder with horror to read of them." 114 They then go on to conclude that the particular punishment under review is clearly not of that type. As a practical matter, ${ }^{115}$ this treatment of the cruel and unusual punishment doctrine virtually removes the prohibition.

\section{B. Judicial Reaction to the Cruel and Unusual Punishment Approach to Banishment}

In the leading case of Weems $v$. United States, ${ }^{110}$ the Supreme Court took a more flexible view of the eighth amendment. Questioning the accuracy of Story's citations, the Court said:

But surely they [the framers of the Bill of Rights] intended more than to register a fear of the forms of abuse that went out of practice with the Stuarts. . . . [I]t must have come to them that there could be exercises of cruelty by laws other than those which inflicted bodily pain or mutilation. ${ }^{117}$

Many state courts have accepted this reasoning. In the course of a steady liberalization of the doctrine, the test of a punishment has at least ostensibly come to be whether "it shocks the conscience and sense of justice of the people of the United States" 118 rather than whether it would have shocked some previous generation of Europeans. ${ }^{119}$

1132 STORY, op. cit. supra note 108 , at 623 .

114 In the Matter of O'Shea, 11 Cal. App. 568, 576, 105 Pac. 776, 779 (Dist. Ct. App. 1909).

115 That it can never be entirely moot was demonstrated by a state representative in Massachusetts who, in 1937, offered a bill for the re-institution of the whipping post, ducking stool and public stocks. Hentig, The Pillory: A Medieval Punishment, 11 ROCKY MT. L. REv. 186 (1939).

116217 U.S. 349 (1910) (4-to-2 decision).

117 Id. at 372. The dissent, joined in by Mr. Justice Holmes, preferred the strict approach.

118 United States v. Rosenberg 195 F.2d 583, 608 (2d Cir.), cert. denied, 344 U.S. 838 (1952), stay of execution granted by Mr. Justice Douglas vacated per curiam after hearing on merits, 346 U.S. 273, 288 (1953).

118 It is not clear whether the conscience referred to is literally that of the "people" or rather that of the presumably more "enlightened" judge. See Judge Frank's discussion in United States v. Rosenberg, 195 F.2d 583, 611 (2d Cir. 1952); Note, 36 N.Y.U.L. REv, 846, 851 (1961). See generally Cahn, Authority and Responsibility, 51 ColuM. L. REv. 838 (1951). 
It has occurred to some that this liberalized interpretation of the cruel and unusual punishment ban offers the only avenue of attack against the practice of banishment, particularly as a condition to executive pardon. An early New York court upholding a condition of banishment said: "The governor may grant a pardon on a condition which does not subject the prisoner to an unusual or cruel punishment." ${ }^{120}$ Although striking down a sentence of banishment in the absence of legislative authority, a recent New York court stated in dictum that such legislation would be valid "unless in the intervening century and a half [since Cooper $v$. Telfair "121 held banishment to be a right of the state] the public ... [mores have] made such punishment cruel and unusual and therefore violative of . . . the Constitution of the State of New York." ${ }^{122}$ One of the few comments that supports banishment on its merits states: "Attack on the constitutionality of the condition here imposed can be founded only on the prohibition against cruel and unusual punishments." 123

These passages, however, do not represent judicial holdings, and most courts have summarily dismissed the idea that banishment might be cruel and unusual. ${ }^{124}$ Rarely have they analyzed their conclusion beyond stating it. One court, although dealing with a different problem, indulged in a lengthy discussion of the physical punishments that were traditionally cruel and unusual and concluded that banishment is not like them. ${ }^{125}$ Another found that banishment "is sanctioned by authority, and has been inflicted, in this form, from the foundation of our government." 126 The only case that has attempted any really extensive investigation of the problem is Legarda $v$. Valdez, ${ }^{127}$ which arose in the Philippine Islands shortly after the turn of the century. This case is the single authoritative pillar upon which practically all opinions dealing with the question rest. However, it did not involve the type of banishment for which it is usually used as authority. The banishment in Legarda was only for a term of years, appeared to have some rehabilitative motivation behind it, and only forbade the offender access to certain cities. It does not, therefore, fall within the definition

120 People v. Potter, 1 Parker, Cr. R. 47, 56-57, 1 Edm. Sel. Cas. 235, 245 (N.Y. Sup. Ct. 1846).

1214 U.S. (4 Dall.) 14 (1800).

122 People v. Wallace, 124 N.Y.S.2d 201, 204 (Suffolk County Ct. 1953).

12330 Colums. L. REv. 1057 (1930); cf. Navasky, Deportation as Punishment, 27 U. Kan. City L. Rev. 213, 218 (1959).

124 E.g., Legarda v. Valdez, 1 Philippine 146 (1902); People v. Baum, 251 Mich. 187, 231 N.W. 95 (1930); People v. Potter, 1 Parker, Cr. R. 47, 1 Edm. Sel. Cas. 235 (N.Y. Sup. Ct. 1846). 125 See State v. Woodward, 68 W. Va. 66, 69 S.E. 385 (1910) (dictum). 126 People v. Potter, 1 Parker, Cr. R. 47, 57, 1 Edm. Sel. Cas. 235, 245 (N.Y. Sup. Ct. 1846).

1271 Philippine 146 (1902). 
of objectionable banishment. In addition, Weems $v$. United States ${ }^{128}$ had not yet been decided. All citations in Legarda represented the school of thought that required physical torture as the touchstone for unconstitutional cruelty. ${ }^{129}$

\section{The Terms of the Constitutional Ban}

\section{Punishment}

Does banishment constitute punishment? Clearly it does when imposed by sentence. The difficulty arises when it is a condition of pardon. In dealing with deportation, the Supreme Court has said that "[deportation] is the forfeiture for misconduct of a residence in this country. Such a forfeiture is a penalty." 130 The theory behind this approach seems to be that something normally considered to be punishment should not lose that denotation by being subsumed in a purportedly non-penal act. "The theory upon which our political institutions rest is, that all men have certain inalienable rights . . . A Any deprivation or suspension of any of these rights for past conduct is punishment, and can be in no otherwise defined." 131 The same reasoning can be applied to banishment by pardon. Justices Brewer and Peckham, though not dealing with the eighth amendment, adopted the statement of one commentator that "Banishment is always [a punishment ] . . . , for a mark of infamy cannot be set on any one, but with a view of punishing him for a fault, either real or pretended." 132 The same characterization was used when a federal court struck down the Exclusion Acts of 1882,1884 , and $1888^{133}$ as bills of attainder. ${ }^{134}$ This approach supports the proposition that the punitive nature of banishment infects any device by which it is dispensed. In two recent cases the Court made it clear that the closely analogous sanction of expatriation could be considered only as punishment. ${ }^{135}$

There are instances-sterilization and deportation being the two most prominent examples-of apparently punitive sanctions which do not constitute punishment. Neither of these is analogous to banishment. Sterilization laws will not be upheld without a clear demonstra-

128217 U.S. 349 (1910); see note 116 supra and accompanying text.

129 Accord, Wilkerson v. Utah, 99 U.S. 130 (1878).

130 Fong Haw Tan v. Phelan, 333 U.S. 6, 10 (1948).

131 Cummings v. Missouri, 71 U.S. (4 Wall.) 277, 321-22 (1866).

132 United States v. Ju Toy, 198 U.S. 253, 270 (1905) (dissenting opinion). See Comment, 56 MicH. L. ReV. 1142, 1163 (1958).

133 Act of May 6, 1882, ch. 126, 22 Stat. 58; Act of July 5, 1884, ch. 220, 23

Stat. 115; Act of Oct. 1, 1888, ch. 1064, 25 Stat. 504.

134 In re Yung Sing Hee, 36 Fed. 437 (C.C.D. Ore. 1888).

135 Kennedy v. Mindoza-Martinez, Rusk v. Cort, 31 U.S.L. WEEK 4159, 4165 (U.S. Feb. 18, 1963). 
tion of valid eugenic rather than penal purpose. ${ }^{136}$ Deportation of aliens has been justified on the ground that the federal government's control of aliens is administrative rather than penal. ${ }^{137}$ It would be difficult to maintain that banishment of citizens by pardon is similarly concerned with some valid non-punitive purpose. Only by defining punishment solely in terms of retribution can pardon be said to be entirely outside the penal framework.

\section{Unusual}

Is banishment unusual? Even Legarda v. Valdez indicated that it is. ${ }^{138}$ Under the strictest interpretation, an unusual punishment would be one that was unknown at common law or obsolete at the time of enactment of the relevant constitutional provision. ${ }^{139}$ No court, however, adheres to that restrictive view. Rather, "any punishment which if ever employed at all, has become altogether obsolete, must certainly be looked upon as "unusual." 140 Moreover, most courts do not insist upon complete obsolescence. The generally accepted meaning of the word unusual is the "ordinary one, signifying something different from that which is generally done." 141

Few courts today would acknowledge a punishment to be cruel and then refuse to strike it down because the cruelty was widespread. Unusualness seems to have been absorbed into the concept of cruelty. It survives only to flavor the total prohibition with a sense of the bizarre. It may also serve as a useful makeweight where a court cannot or does not care to reconcile its own misgivings with the less squeamish convictions of the public at large. ${ }^{142}$

By any definition, banishment must surely be considered unusual. It is infrequently invoked, invalid as a sentence, and undoubtedly seems archaic to the general public, most of whom probably do not even know that it still exists.

\section{Cruelty}

The crucial question is whether banishment is cruel. The courts are developing a two-pronged approach to the definition of cruelty

136 See Buck v. Bell, 274 U.S. 200 (1927); State v. Feilen, 70 Wash. 65, 126 Pac. 75 (1912); cf. Skinner v. Oklahoma ex rel. Williamson, 316 U.S. 535 (1942). Contra, Davis v. Berry, 216 Fed. 413 (S.D. Iowa 1914).

137 Costanzo v. Tillinghast, 56 F.2d 566 (1st Cir. 1932).

138 See 1 Philippine 146, 148 (1902); 32 N.C.L. REv. 221, 224 (1954).

1391 Cooley, Constitutional Limitations 694 (8th ed. 1927).

140 Ibid.

141 Trop v. Dulles, 356 U.S. 86, 100 n.32 (1958).

142 The "unusual" requirement has been particularly useful in this respect in cases involving capital punishment. E.g., Wilkerson v. Utah, 99 U.S. 130 (1878). 
involving the concepts of disproportionate punishment and intrinsic cruelty.

\section{a. Disproportionate Punishment}

The notion that "punishment should . . . be made to fit the crime and not the offender" ${ }^{148}$ might seem foreign to modern theories of individualized justice. ${ }^{144}$ But justice dispensed by men can never be perfectly individualized. At the boundaries of permissible severity the sentence must bear some relation to the offense. It is now clear that a punishment of disproportionate or inappropriate severity can be unconstitutional. "[W]e believe that it is a precept of justice that punishment for crime should be graduated and proportioned to offense." ${ }^{145}$ In setting the outer limits of permissible punishment, Weems $v$. United States looked directly to whether the valid purposes of punishment were served by the particular sanction imposed. A later Supreme Court opinion ${ }^{146}$ has been interpreted to mean that "due process is denied if punishment and offense have no rational relation." 147 In a recent decision, the Court held unconstitutional a California statute making narcotics addiction a crime. Stating that addiction is an illness, the Court said:

To be sure, imprisonment for ninety days is not, in the abstract, a punishment which is either cruel or unusual. But the question cannot be considered in the abstract. Even one day in prison would be a cruel and unusual punishment for the "crime" of having a common cold. ${ }^{148}$

Mr. Justice Douglas, in a concurring opinion, stated that even a fine would be cruel and unusual if imposed for sickness. He further declared:

The purpose of . . [ [the statute] is not to cure, but to penalize. Were the purpose to cure, there would be no need for a mandatory jail term of not less than 90 days. . . . I

143 Cason v. State, 160 Tenn. 267, 271, 23 S.W.2d 665, 667 (1930).

144 See Glugck, Probation and Crmannal Justice 100 (1933) ; Brown, West Virginia Indeterminate Sentence and Parole Laws, 59 W. VA. L. REv. 143 (1957); Glueck, Indeterminate Sentences and Parole in the Federal System: Some Comments on a Proposal, 21 B.U.L. REv. 20, 21 (1941). Some of the most exquisitely cruel tortures were clearly intended to fit punishment to crime; $e . g$., the penalty for adultery in ancient Hindu law provided that the man be roasted on an iron bed and the woman be devoured by dogs. Fink, Crimes and Punishment Under Ancient Hindu Law, 1 LAw Magazine \& Rev. (4th ser.) 321 (1875).

145 Weems v. United States, 217 U.S. 349, 367 (1910).

146 Louisiana ex rel. Francis v. Resweber, 329 U.S. 459 (1947).

147 Whalen, Punishment for Crime: The Supreme Court and the Constitution, 35 MnNv. L. REv. 109, 122 (1951).

148 Robinson v. California, 370 U.S. 660,667 (1962). 
think the means must stand constitutional scrutiny, as well as the end to be achieved. . . . This prosecution has no relationship to the curing of an illness. Indeed, it cannot, for the prosecution is aimed at penalizing an illness, rather than with providing medical care for it. ${ }^{149}$

The focus, therefore, is on whether there is a valid relationship between means and ends. Imprisoning a dope addict is unconstitutional because the solution is irrelevant to the problem. On this reasoning, banishment should be held to be unconstitutional since it has no relevance to the solution of any problem at all.

There is strong feeling, however, that as long as a punishment is legislatively prescribed and is not intrinsically cruel, it is not to be nullified for its lack of appropriateness in the light of the offense. Courts reasoning this way have refused to overturn some rather disproportionate sentences. ${ }^{150}$ They have also refused to consider such things as unequal treatment of the equally guilty, ${ }^{151}$ anomalous penalties for similar crimes, ${ }^{152}$ and cumulative penalties for technically independent violations. ${ }^{153}$ "It has invariably been held that, no matter how harsh and severe it might seem to this court, yet, if it was within the limits prescribed by statute . . . this court could not . . . reverse the judgment." 154 In deferring to the legislature, the courts often revive the normally moribund "unusual" element of the constitutional prohibition. A usual punishment that also represents the will of the legislature can hardly be cruel. ${ }^{155}$ This idea has been so twisted that one

148 Id. at $676-78$.

150 O'Neil v. Vermont, 144 U.S. 323 (1892) (fifty-four years for 307 separate counts of shipping illegal liquor into a dry state); People v. Gaumer, 7 Ill. 2d 134, 130 N.E.2d 184 (1955) (fifty years for statutory rape); Lester v. State, 209 Miss. 171, 46 So. $2 d 109$ (1950) (twenty years for vehicular manslaughter due to drunkenness) ; Harding v. Commonwealth, 283 Mass. 369, 186 N.E. 556 (1933) (five to eight years for receiving stolen goods worth sixteen cents) ; Commonwealth v. Murphy, 165 Mass. 66, 42 N.E. 504 (1896) (life imprisonment for carnal knowledge of consenting near-16-year-old girl by 16-year-old boy).

151 State v. Eckenfels, 316 S.W.2d 532 (Mo. Sup. Ct. 1958) (co-defendants received sentences of five years and life respectively).

152 Johnson v. State, 214 Ark. 902, 218 S.W.2d 687 (1949) (seven-year manslaughter sentence where minimum for second degree murder is five years); State $v$. White, $44 \mathrm{Kan}$ 514, 25 Pac. 33 (1890) (court granted that penalty for statutory rape was incongruous compared to adultery and seduction penalties).

153 O'Neil v. Vermont, 144 U.S. 323 (1892).

154 Miller v. State, 149 Ind. 607, 613, 49 N.E. 894,896 (1898). This statement was made in the face of a constitutional requirement that a sentence be proportionate to the offense. Where no such requirement exists, courts have even less trouble in avoiding the issue.

155 In People v. Gaumer, 7 IIl. 2d 134, 130 N.E.2d 184 (1955), the defendant received fifty years in prison for statutory rape. The court admitted the sentence was "apparently harsh and severe," id. at 138, 130 N.E.2d at 186, but affirmed it because it was within statutory limits and because an earlier decision by the same court had stated that "sentences of life imprisonment for statutory rape have been upheld by this court." People v. Dixon, 400 I11. 449, 452, 81 N.E.2d 257, 259 (1948). It is parenthetically interesting to note that this statement is false. It rests on a 
court recognized, as a legitimate legislative purpose, the pandering to a public tendency to lawlessness-the word usual was defined in terms of the retributive expectations of the public at large. ${ }^{156}$

Deference to public emotion is somehow easier for an appellate court when an apparently disproportionate sentence is the result of a jury's rather than a judge's decision. ${ }^{157}$ "It may be that the jury's verdict was a harsh one, but they had the witnesses before them and were in a better position to judge of the facts . . . ." 158

\section{b. Intrinsic Cruelty}

A penalty authorized by statute is open to constitutional attack when it can be characterized as intrinsically cruel. ${ }^{159}$ The conception of what constitutes unconstitutional intrinsic cruelty has moved a long way from simple physical brutality. In an early case dealing with cruelty to a slave, the Alabama Supreme Court said:

Cruel, as indicating the infliction of pain of either mind or body, is a word of most extensive application. . . . If a slave should be punished, even without bodily torture, in a manner offensive to modesty, decency, and the recognized proprieties of social life, the offender would be chargeable ... 160

Another early decision forbade, under a statute directed only at cruel punishment, the "cruel, unusual, unnatural and ludicrous punishment" of ducking. ${ }^{161} \mathrm{Mr}$. Justice Field, while riding circuit in California, expressed his views about psychological cruelty in an opinion

mis-citation by the court in Dixon of three cases that could hardly be relevant to statutory rape since they all involved violence of the most brutal variety: People $v$. Mundro, 326 III. 324, 157 N.E. 167 (1927); People v. Poole, 284 I11. 39, 119 N.E. 916 (1918); People v. Rardin, 255 IIl. 9, 99 N.E. 59 (1912).

156 Hart v. Commonwealth, 131 Va. 726, 109 S.E. 582 (1921). A sentence of electrocution for attempted rape was affirmed. The court said:

It is well known that public indignation is as much aroused by the one offense [attempt] as the other [rape]. . . And the almost universal repugnance which exists in the public mind . ... and the general aversion to the putting of the prosecutrix through the indecent and harrowing ordeal of having to testify in court upon such a subject, are well known. The likelihood of the resort to lynch law, unless there is a prompt conviction and a severe penalty imposed, and thus a resultant grave shock to the peace and dignity of the commonwealth, is well known to exist ... These are considerations which the legislature properly could ... take into account ... as an element of the measure of the punishment.

Id. at 746-47, 109 S.E at 588.

167 Pineda v. State, 157 Tex. Crim. 609, 252 S.W.2d 177 (1952) (ten years for indecent exposure); Missouri v. Edmonson, 309 S.W.2d 616 (Mo. Sup. Ct. 1958) (five years for a felon's driving a car without permission).

158 Reeves v. State, 145 Tex. Crim. 208, 214, 167 S.W.2d 176, 180 (1943).

159 State v. Devore, 225 Iowa 815, 281 N.W. 740 (1938).

160 Turnipseed v. State, 6 Ala. 664, 665 (1844). (Emphasis added.)

161 James v. Commonwealth, 12 S. \& R. 220, 225 ( $\mathrm{Pa} .1825$ ). 
awarding damages to a Chinese plaintiff whose queue had been cut off pursuant to a discriminatory misdemeanor ordinance:

Probably the bastinado, or the knout, or the thumbscrew, or the rack, would accomplish the same end; and no doubt the Chinaman would prefer either of these modes of torture to that which entails upon him disgrace among his countrymen and carries with it the constant dread of misfortune and suffering after death. ${ }^{162}$

In Weems v. United States, the Supreme Court declared: "A principle to be vital must be capable of wider application than the mischief which gave it birth" 163 and proceeded to articulate a major break with the old notion of the character of cruelty. The punishment imposed was fifteen years at hard labor in chains, with burdensome lifetime control after release. ${ }^{164}$ Despite the fact that no physical torture was involved, the punishment was found offensive not only because it was disproportionate but also because of its intrinsic character. ${ }^{165}$

In a more recent case, the Court rejected the claim of a convicted murderer, who had been subjected to an unsuccessful electrocution attempt, that his execution would constitute cruel and unusual punishment. ${ }^{166}$ But all of the justices recognized that cruelty can be extreme although not in any way physical.

This developing standard has also been applied in deportation cases. The courts have often expressed awareness of the extreme cruelty of that practice. It is significant that banishment is often mentioned by way of analogy to the cruelty inflicted upon a deported alien who has acquired roots in this country. The strong implication is that deportation would be unconstitutional, if, like banishment, it could be considered as punishment rather than as the mere administrative regulation of aliens who have no inherent right to remain in the country. Speaking of the alien and sedition laws of 1798, James Madison said:

If the banishment of an alien from a country into which he has been invited as the asylum most auspicious to his happiness,-a country where he may have formed the most tender connections; where he may have invested his entire property, and acquired property of the real and permanent, as well as the movable and temporary kind; where he enjoys, under the laws, a greater share of the blessings of personal

162 Ho Ah Kow v. Nunan, 12 Fed. Cas. 252, 255 (No. 6546) (C.C.D. Cal. 1879). 163217 U.S. 349, 373 (1910).

104 The punishment was a legacy of Spanish rule called cadena temporal and the statutory minimum was twelve years.

165217 U.S. at 377.

168 Louisiana ex rel. Francis v. Resweber, 329 U.S. 459 (1947). 
security, and personal liberty, than he can elsewhere hope for; . . . if a banishment of this sort be not a punishment, and among the severest of punishments, it will be difficult to imagine a doom to which the name can be applied. ${ }^{167}$

Judge Augustus Hand declared that exile is a "dreadful punishment, abandoned by the common consent of all civilized peoples." It is "cruel and barbarous," and a "national reproach." ${ }^{168}$ In a fairly recent decision, the Supreme Court said that "deportation is a drastic measure and at times the equivalent of banishment . . . ." 169 Thus the dissatisfaction with the deportation laws is commonly expressed in terms of a comparison to something assumed to be unconstitutionalbanishment of a citizen. ${ }^{170}$

The same considerations apply to banishment from a state or city as to expulsion from the country. An important psychological factor that is actually most applicable in the context of local banishment is the perpetual pall of criminality under which the individual must live out his life. ${ }^{171}$ This stigmatization is all the more insidious because of the seductive appeal it holds for the convict who welcomes it. The allure of an immediate "good deal," particularly to the type of person likely to be faced with the situation, obscures long range consideration. The convict sells his future as readily as he might sell his soul were he approached by the appropriate authority. The full significance of his decision is felt only when choice is no longer available, and when the originally undesirable alternative would long have been forgotten. ${ }^{172}$

Something more than dictum can be appealed to in support of this notion of intrinsic unconstitutional cruelty. In a recent case, ${ }^{173}$ four members of the Supreme Court held expatriation of a soldier for desertion in wartime to be cruel and unusual. Mr. Chief Justice Warren defined unconstitutional cruelty in broad terms comprised en-

167 Madison's Report on the Virginia Resolutions (1800), in 4 ErLlot's DeBaTES on the FEDERAL CoNSTItution 546, 555 (2d ed. 1901).

168 United States ex rel. Klonis v. Davis, 13 F.2d 630, 631 (2d Cir. 1926).

169 Fong Haw Tan v. Phelan, 333 U.S. 6, 10 (1948).

170 However, in Vitale v. Hunter, 206 F.2d 826 (10th Cir. 1953), the court reimposed a fifteen-year sentence on a deported narcotics violator on the grounds that he had breached his contract with the President by violating the terms of his commutation. No direct reference was made to his status as an alien as having a bearing on the reimposition of the sentence. The implication is that this court would have come to the same decision in the case of a citizen.

171 The lifetime "accessory" controls imposed on the convict in Weems v. United States, 217 U.S. 349 (1910), were a chief element in the unconstitutional cruelty of the punishment there involved.

172 Cf. Benet, The Devil and Dantel Webster (1939).

173 Trop v. Dulles, 356 U.S. 86 (1958). 
tirely of non-physical factors. ${ }^{174}$ The eighth amendment, said the Chief Justice, is concerned with "nothing less than the dignity of man" and therefore a state must punish "within the limits of civilized standards." Expatriation was considered cruel because it "subjects the individual to a fate of ever increasing fear and distress," and destroys his "status in organized society." 175

Mr. Justice Brennan concurred on broader grounds that made it unnecessary for him to reach the eighth amendment point. ${ }^{178}$ His feelings on that matter, however, are reasonably clear. He recognized the "uncertainty and the consequent psychological hurt" inherent in expatriation. He found it to be insidious and "an especially demoralizing sanction." $177 \mathrm{He}$ examined rather carefully the question of penological justification as a counterbalance to cruelty:

It is perfectly obvious that it [expatriation] constitutes the very antithesis of rehabilitation, for instead of guiding the offender back into the useful paths of society it excommunicates him and makes him, literally, an outcast. I can think of no more certain way in which to make a man in whom perhaps, rest the seeds of serious antisocial behavior more likely to pursue further a career of unlawful activity than to place on him the stigma of the derelict, uncertain of many of his basic rights. ${ }^{178}$

These arguments apply equally to banishment, most particularly to the usual interstate banishment under which the convict remains within the bounds of the national society under conditions that closely parallel those of the expatriate. From this expanded concept of cruelty, no additional step need be taken to reach banishment. In fact, expatriation is less terrifying than banishment. It involves merely a loss of status in a community, not expulsion from it. ${ }^{179} \mathrm{Mr}$. Chief Justice Warren stated that one of the most fearsome attributes of the

$174 \mathrm{Mr}$. Justice Frankfurter's dissent asked: "Is constitutional dialectic so empty of reason that it can be seriously urged that loss of citizenship is a fate worse than death?" 356 U.S. at 125 . The dangers of judging cruelty in terms of the death penalty are pointed out in Comment, 56 MICH. L. REv. 1142, 1162 (1958).

175356 U.S. at $100-02$.

176 Justice Brennan said that expatriation in this case was not within congressional power to enact. He voted with the majority in Perez v. Brownell, 356 U.S. 44 (1958), which was decided the same day and held that expatriation of a nonpunitive nature for voting in a foreign election was within congressional authority.

177356 U.S. at 110-11.

178 Id. at 111. See also an excellent Note on the Expatriation Act of 1954 which is relied on directly by the majority, 356 U.S. at $101 \mathrm{n.33}$, and which says, "Economy to the state is perhaps the only objective of punishment which expatriation is certain to serve." Note, 64 Yale L.J. 1164, 1193 (1955).

179 "The danger of expulsion, and its consequences, is by far the most serious consequence of expatriation." Id. at 1195. 
unconstitutional cruelty inflicted upon an expatriate is the fact that "he may be subject to banishment, a fate universally decried by civilized people." 180

\section{Conclusion}

It would seem that a practice "universally decried by civilized people" should have no place in a modern, purportedly civilized, society. Banishment has retained something of the place it once shared with the thumbscrew, the rack, and other medieval refinements chiefly because of the subtle nature of its barbarism and its practical usefulness in the deflection of difficult political or social problems.

This sort of misuse can be ended once and for all by judicial recognition of the fact that banishment fits well within the modern conception of the prohibition against cruel and unusual punishment. A finding to that effect would remove from practice and consideration an archaic device whose only place in a modern world should be in fiction and history books. 